\title{
International Students: What's Missing and What Matters
}

\section{Pallavi Singh ${ }^{1 *}$, Kimberley Williams ${ }^{2}$, Ratnaditya Jonnalagadda ${ }^{3}$, Avinash Gogineni ${ }^{4}$, Roopesh Reddy Sadashiva Reddy 5}

\author{
${ }^{1}$ Steve Hicks School of Social Work, The University of Texas at Austin, Austin, TX, USA \\ ${ }^{2}$ Bert S. Turner Department of Construction Management, Louisiana State University, Baton Rouge, LA, USA \\ ${ }^{3}$ Wharton Business School, University of Pennsylvania, Philadelphia, PA, USA \\ ${ }^{4}$ Miller School of Medicine, University of Miami, Miami, FL, USA \\ ${ }^{5}$ Sylvester Cancer Research Center, University of Miami, Miami, FL, USA \\ Email: *pallavi.singh@austin.utexas.edu
}

How to cite this paper: Singh, P., Williams, K., Jonnalagadda, R., Gogineni, A., \& Reddy, R. R. S. (2022). International Students: What's Missing and What Matters. Open Journal of Social Sciences, 10, 381-397. https://doi.org/10.4236/jss.2022.102027

Received: January 30, 2022

Accepted: February 22, 2022

Published: February 25, 2022

Copyright (c) 2022 by author(s) and Scientific Research Publishing Inc. This work is licensed under the Creative Commons Attribution International License (CC BY 4.0).

http://creativecommons.org/licenses/by/4.0/

(c) (i) Open Access

\begin{abstract}
With a growing number of international graduate students pursuing degrees in the United States, it is essential that universities understand the unique challenges this population faces. In this study, we researched the role that university's international graduate student housing plays in building a sense of community among international students. This qualitative study explored 17 international graduate students lived experience in the United States regarding sense of community within the graduate housing complex. Findings suggest that international student residents faced several issues; these included satisfaction with their accommodation, the way their fellow neighbors conducted themselves in university housing and preferring to reach out to other international students from their home country. However, they were able to find support within other departments and smaller communities within university. Recommendations are presented to practitioners and future researchers so that they can effectively develop support for international graduate students.
\end{abstract}

\section{Keywords}

International Graduate Student, Graduate Housing, Sense of Community

\section{Introduction}

The 2020 report on International Educational Exchange (IIE) discloses that over a million international students enrolled at USA universities during the 2019/2020 academic year (IIE, 2020). International students contribute to the 
United States in many ways, such as growing the economy and helping the nation lead in innovation (Hegarty 2014; NAFSA, 2019). In addition, international students, particularly those in graduate schools, bring a wide range of skills and knowledge, thus enriching the intellectual capital of United States universities and the nation's workforce (Zhang, 2016).

Although the financial gain that international students can bring to a campus is one of the main reasons for their recruitment (Altbach \& Engberg, 2014; Beine et al., 2014; NAFSA, 2019), some studies attest to the variety of ways in which international students can enrich the academic community. Examples of this include differing points of views that can often enrich classroom discussions and also students learning to appreciate other cultures and relate to others from different backgrounds (Bevis, 2002; Lee \& Rice, 2007; Urban \& Palmer, 2014). Moreover, international students help increase the global reputation of the University (Hénard et al., 2012; Ward, 2001). Therefore, merely treating international students as an instrument of financial capital diminishes the status of international students and can be considered unidimensional as this approach would remove any sense of humanity from the experiences of international students (Slantcheva-Durst \& Knaggs, 2019).

How international students' presence on campus is leveraged and to what extent they integrate into the campus community are equally important especially for their well-being and mental health (Prieto-Welch, 2016; Sullivan \& Kashubeck-West, 2015; Webber et al., 2013). Researchers estimate that $15 \%-20 \%$ of international students are at risk of experiencing mental health problems due to a lack of community (Zhang \& Goodson, 2011). Coming to the United States also creates additional stress, as these students may have prolonged stress resulting from the actual decision to migrate and their separation from their families and friends (Akinsulure-Smith \& O'Hara, 2012). These life changes can be a result of many factors that include differences in climate, dietary options, or lifestyle choices (Pendse \& Inman, 2017). International students often miss their community back home and consequently look for ways on how they can build a new community that can alleviate the stress that migrates to a new country brings.

On-campus housing often allows and encourages those students to find their sense of community through experiences with diverse peers (Supiano, 2018). These interactions have been linked to a positive correlation between their sense of community and their satisfaction with their institution (Supiano, 2018; Joseph, 2021). In addition, on-campus housing also allows students access to many on-campus resources such as libraries, dining areas, recreational facilities, and many more depending on the university (Johnston, 2016).

There has been extensive research on sense of community among international students and the role campus resources (both academic and extracurricular initiative) play (Chen \& Zhou, 2019; Heng, 2017; Metro-Roland, 2018). Additionally, there is research about the role on-campus housing for undergraduate students play in building a sense of community (Arthur, 2017; Hart, 2021; Yao, 2014). However, the role student housing plays in building a sense of communi- 
ty particularly among international graduate students has received much less attention. Consequently, it remains unclear to educators, researchers, and university administrators what international student experiences are in a place they call home in a foreign land and the role they play in building a sense of community. This article helps fill in this gap.

Focus groups were the major source of data for this study. Our research team organized two focus groups, with a total of 17 purposefully sampled international graduate students. The focus group discussions took place over a period of two months at a large southern university. Students were formally invited to participate. Open-ended questions were presented to the focus groups to examine the participants' experiences regarding international graduate student housing and their perception of community within it. What emerged from these conversations was an understanding of the major areas of engagement for international students on student housing, the factors mostly impacting students' involvement according to the students themselves, and the students' perceptions of their own connectedness to the housing environment.

\section{Purpose of This Study}

The objective of this study is to explore international students' lived experience and sense of community to their new place of residence (international graduate student housing). Understanding this process will provide knowledge of factors that may serve as the role housing plays in developing a sense of community among international graduate students. In addition, acquiring knowledge of factors affecting international student sense of community may result in development of specific university programming aimed to make international students feel welcomed and at home.

\section{Literature}

\subsection{Sense of Community}

A major focus of higher education is the increased attention given to the importance of a strong sense of community (Hausmann et al., 2007; Museus et al., 2018; Strayhorn, 2018). Sense of community was initially operationalized by McMillan \& Chavis, (1986), who developed a theoretical model of sense of community, which consists of four components: membership; influence; integration and fulfilment of needs; and shared emotional connections. Membership refers to the feeling of belonging to a group (McMillan \& Chavis, 1986). Influence is a reciprocal relationship whereby group members influence the community and the community influences members (McMillan \& Chavis, 1986). Reciprocally, each influence and pressures the other to perform tasks and/or conform to rules (Unger \& Wandersman, 1985). Integration and need satisfaction are concerned with the notion that group association is rewarding for its members (McMillan \& Chavis, 1986). Group members believe that community resources will meet their needs (Duffy \& Wong, 1996). Shared emotional connec- 
tions are based on members' identification of a shared history (McMillan \& Chavis, 1986). People only have to identify with that history rather than physically share it (Unger \& Wandersman, 1985). These definitions suggest the most essential elements of community are: mutual interdependence among members, sense of belonging, connectedness, spirit, trust, interactivity, common expectations, shared values and goals, and overlapping histories among members.

\subsection{International Student Sense of Community}

An important facet of the college student social context is the way in which students perceive their community, defined as psychological sense of community (McCarthy et al., 1990). Sarason (1974) defines psychological sense of community as "the perception of similarity to others, and acknowledged interdependence with others, a willingness to maintain this interdependence by giving to or doing for others what one expects from them ... and the feeling that one is part of a larger dependable and stable structure ...” (p. 157).

International students are not part of the dominant campus culture due to their different cultural backgrounds and temporary citizenship status. Prior research done on the experiences of international students suggests that international students can experience many challenges as a result of language and cultural barriers, academic and financial difficulties, interpersonal problems, racial discrimination, acculturative stress, loss of social support, alienation, and homesickness. Under such circumstances international students look to build a sense of community to combat these struggles (Hendrickson et al., 2011; Smith \& Khawaja, 2011; Sun et al., 2016; Thurber \& Walton, 2012; Alharbi \& Smith, 2018; Wu et al., 2015).

\subsection{Sense of Community in University Housing}

A positive social environment not only consists of social ties and interactions with family and friends in the community but also the level of one's involvement in their community (Amérigo \& Aragonés, 1997; Fried, 1984; Unger \& Wandersman, 1985; Wasserman, 1982). McDonald (2002) explain that college campuses "have a need for community; it is a primal yearning and a practical necessity. Community is supported by shared purpose, shared commitment, shared relationships, and shared responsibility" (p. 3).

The shared experience by interacting creates opportunities for personal and communal growth. Community development leads to positive outcomes such as student development and retention (Tinto, 1993). However, lack of involvement in activities and not spending time in social gatherings are seen as barriers to building a sense of community (Astin, 1993). The interactions provided by being involved in one's community increase the sense of community, which in turn creates residential satisfaction (Amérigo \& Aragonés, 1997; James et al., 2008; Wasserman, 1982). Many environmental factors such as lack of space and overcrowding do not support community development (Moos, 1986; Schroeder \& 
Mable, 1994). Through these experiences, students are able to form smaller communal groups with others who share similar interests. They can then support each other through the challenges of being an international student on a large campus.

Related to aesthetic pleasantness, community satisfaction has been found to be determined by the neatness and cleanliness of the community in that the more aesthetically pleasing an area, the higher the level of connection to the housing community (Adriaanse, 2007; Aiello et al., 2010; da Luz Reis \& Dias Lay, 2009; Grzeskowiak et al., 2006; Hourihan, 1984; Hughey \& Bardo, 1984; James et al., 2008; Perez et al., 2001; Uzzell et al., 2002). A study by Hourihan (1984) indicated that neatness and cleanliness play a role in satisfaction with the housing. Furthermore, articles about college housing design by Biliczky (2005) and McKee (2005) note the importance of community and the need to provide space to students so they may socialize and interact rather than spend too much time in their rooms.

In summary, essential elements of sense of community are mutual interdependence, spirit, trust, interactivity, common expectations, shared values. For any college student, the way they perceive their community depends on perception of similarity and interdependence with others as well the feeling that one is part of something larger and stable. The international student struggle to build a sense of community (due to their cultural differences and/or temporary visa status). Therefore, a positive social environment that consists of social ties and interaction with their fellow international graduate student in the housing complex provides an opportunity to feel a part of community.

\section{Methodology}

We employed a qualitative method to this study to describe international students' perceptions, experiences, and emotions regarding the resources and community activities provided by graduate housing to strengthen the sense of community. Qualitative inquiries in the form of semi-structured focus group interviews were deemed appropriate to guide the investigation because of the exploratory nature of the study and the heightened possibility of obtaining rich and detailed knowledge from the participants (Denzin \& Lincoln, 1994). The qualitative approach allowed the presentation of details of their experiences to reflect their multifaceted and complex realities (Bogdan \& Biklen, 2003).

\subsection{Sampling and Participants}

This study used purposeful sampling, an approach in which the researcher deliberately proceeds with a selection of information-rich cases "from which one can learn a great deal about issues of central importance to the purpose of the inquiry" (Patton, 2002: p. 230). The international students were defined following the Organization for Economic Co-operation and Development's (OECD, 2017) definition that "international students are those students who left their country of origin and moved to another country for the purpose of study" (p. 70). In this 
study, we recruited international students who resided in international graduate housing at the university for a minimum of two semesters. A total of 17 students participated in this study. Six participants were female and eleven participants were male. Seven participants were from Asia, nine were from Africa, and one was from South America.

\subsection{Data Collection Procedures}

Qualitative, semi-structured focus groups were the primary source of data for this study. Open-ended questions were presented to the focus groups, and probing questions were also used based on participants' responses. The questions were aimed to examine the participants' experiences regarding international graduate student housing and the programs offered by it at the southern university they were attending. Two focus groups were interviewed, each lasting a little over 90 minutes. Each focus group was recorded using a digital recording device, and a graduate student (that worked with the authors) transcribed the responses.

\subsection{Data Analysis}

Data was analyzed using an inductive approach. According to LeCompte \& Preissle (1993), this approach entails scanning the data to search for categories of a given phenomenon and then searching for relationships among those categories. Relationships were examined based on each case, and negative instance were noted while expanding the original constructs (LeCompte \& Preissle, 1993). Data was compared, contrasted, aggregated, and ordered to find common categories. Once categories were formed, linkages and relationships were sought within the resulting data structure. The core categories and themes were compiled, summarized, and reported. In the process of reconstructing narratives, direct quotes from the transcript were extracted to stay as close to the original data as possible in reporting findings.

\section{Results and Discussion}

The in-depth focus groups with the international graduate students who resided in a graduate housing facility provided by the university, provided rich and diverse accounts of how international students perceive and form a sense of community. Several common themes emerged such as residential satisfaction plays a role in building a sense of community, and the way neighbors interact and conduct themselves also affects the sense of community among its residences, the residences find a sense of community by engaging with other international graduate student from their home country and finally, international student find their community using other avenues. These themes are discussed in detail below.

\subsection{Residential Satisfaction and Sense of Community}

A lack of residential satisfaction was reflected in students' lack of sense of com- 
munity. In general, students suggested that the lack of maintenance and hygiene led them to spend large amounts of time inside their homes. The responses from the international students also indicated that the maintenance in graduate student housing was not optimal. The residents unanimously raised the concern that pest control was not done regularly and that any raised requests took at least a month to get addressed. However, international students stated that since the pricing was very reasonable, they preferred to stay in the graduate housing.

When we say that there is hygiene problem $[s]$ or roaches, there are things that are supposed to be done right, but maintenance is taking [too] long.

I think maintenance. It's something that probably can be enforced. We have talked about hygiene, and I know they try to do inspection and they leave a notice like warning that the place wasn't hygienic enough. But I still feel that something more should be done. Or at least carry inspection more often.

And the laundry room. They should do more. I don't know whose responsibility [it is] to clean them, but they are not very clean.

These sentiments reflect earlier research. For example, Potter \& Cantarero (2006) found that physical environments such as neighborhoods were considered important factors in feeling a sense of community. A person's satisfaction with the community services and facilities also increased their commitment to that community (Miller et al., 1980).

\subsection{Neighbors' Conduct versus Sens of Community}

Neighbors are not complete strangers, nor are they bound by common interest (Terruhn \& Ye, 2021). Encounters with them are, by nature of proximity, typically recurring in their familiarized locales. Both the importance of low-key, pragmatic exchanges and adherence to codes of neighborly conduct are appropriate (Burrell, 2016). This demonstrates the significance of low-pressure, light-touch norms of neighboring for generating a sense of familiarity, comfort, and reassurance (Burrell, 2016) that is productive for day-to-day living. Participants also highlighted, however, that there are differences in how well neighbors adhered to these codes of conduct. It was in such reflections on who adhered or refused to adhere to these tacit rules that difference and diversity became salient.

I have a problem when it comes to people leaving trash outside the doors and not being sensitive enough like in common areas, and just hanging clothes outside in [a] balcony, you know.

I don't think I will feel a sense of community when there is trash outside the door and kids [are] stomping outside my door unsupervised. P m like, really?

It is adherence to such codes of conduct that organizes a network of neighborly encounters and sense of community. Lack of adherence leads to a lower level of interactions. Research by Farrell et al. (2004) found that a lower level of engagement leads to a lower sense of community.

Yes, I tried to talk to them, you know, asking can you remove this, it is not right. But the next time (inaudible), but I don't want to interpret. 
Research by Smith (2011) found that neighborhoods where neighbors don't respect the social norms experience a lower sense of community as residents feel less safe and secure and unwelcomed. As a result, they withdraw from each other and interact less, resulting in less of a sense of community forming (Brodsky, 1996; Unger \& Wandersman, 1985; Wilson-Doenges, 2000; Wood et al., 2010).

\subsection{Engaging with Their Own}

Group members are drawn together through sharing a common interest, resulting in the development of social ties and identification with other members of that group (BeLue et al., 2006; Chavis \& Newbrough, 1986; Evans, 2009; Farrell et al., 2004; O'Grady \& Fisher, 2008). Being a member of a community, group, or organization results in a person developing a sense of community, an emotional connection to other people, and a feeling that their needs are being met (Farrell et al., 2004; Obst \& White, 2007). This reflects McMillan and Chavis' (1986) theorized components of sense of community.

The process of building a sense of community or being part of a community is associated with the relationships developed outside of students' own ethnic groups or other international student groups on campus (Andrade \& Evans, 2009; Olivas \& Lee, 2006; Ward et al., 2008). In this study, the international students we spoke with shared strong ties with other international students from their home countries. Research on international students documents these students' propensity to maintain strong relationships with people from their home countries or students from other nations rather than with American students (Kwon, 2009; Zhao et al., 2005). As Mori (2000) stated, “international students' warm, intimate, comforting contacts are almost solely confined to their own national groups" (p. 138).

Yes, there are cultural differences because obviously being human there are differences. But it's individual differences. Like, if I like Kenyan foods, I will visit. For me, I like to hang out with (name) kids. So ...

I like cooking my own food. I don't know about the Americans, if they like doing that. So, I will more likely hang out with internationals who do the things I like doing. We cook ugali and eat, and so that ...

Language barriers, diverse cultural norms, and time to engage in social activities may surface as barriers for social interactions between local and international students (Trice, 2004). As a group, international students were often far more motivated to interact with other international students from other countries than local students. As a result, friendship development may occur more frequently with co-nationals or other international students than with local students (Kashima \& Loh, 2006). The findings suggest the majority of the international students created social networks among other international students that mostly excluded Americans (Rose-Redwood \& Rose-Redwood, 2013). International students who identified with more integration among American students limited their interactions to mostly work, academic, and professional expe- 
riences, with few interactions identified as social networking.

\subsection{Engaging with Their Own}

This large public research university provides a variety of different programs and staff to help support international students. Many students talked about the difficulty of finding these resources. For example, one participant said the following:

It's difficult to do all that because of size [of the university,] and that's why ICC (International Cultural Center) helps. That's how I was able to contact [name of another international student]. So, they didn't do it directly, but they have these platforms which facilitates [it].

Participants talked about how other departments and avenues provide support and how connection within their countries' cultural associations fosters their sense of community. It is evident that international students have contact with their countries' student associations.

It's not like there is no information because there are channels like students' organizations ICC and something like ISO (International Student Office). So, there are channels.

Support for international graduate students at the institution came from the presence of fellow students from their home countries. Again, these connections mirror the surrogate families seen in the literature (McLachlan \& Justice, 2009). At this institution, these groups vary greatly in size and involvement, and each student's interactions and involvement differed depending on how strong the community was. This research was conducted in a very large research university in the southern part of the United States. This research is consistent with similar findings taken from what students attending larger research institutions have self-reported. Small liberal arts institutions have continuously shown similar exposure to diverse experiences, even with much smaller student bodies and often in much less diverse locations (Hu \& Kuh, 2003; Kuh, 2009).

I came from a small university with a small community, and they took care of all that stuff. But when you look at [University], it's difficult to do all that because of size, and that's why ICC helps. That's how I was able to contact (name). So, they didn't do it directly, but they have these platforms which facilitate.

While colleges can organize special events focusing on students' different cultures, employing different international student organizations offers a powerful venue for learning from those students. Such organizations seemed more effective at facilitating co-curricular interactions than anything else mentioned by our participants, and also provided the opportunity for international students to act as agents of internationalization, sharing their cultures, holidays, customs, and foods with American and other international students.

\section{Recommendation and Conclusion}

Participants in this study discussed their experiences with graduate housing for international students and their perception of sense of community. Findings 
conclude that residential satisfaction is related to sense of community and neighbor conduct leads to a lack of sense of community. International students prefer to engage with other international students from their own country. The next section lays out the recommendation for both international graduate housing as well as for university administration.

Cheng (2004) suggests that "students' sense of community is closely associated with their feelings of being cared about, treated in a caring way, valued as an individual and accepted as a part of community, and the quality social life on campus." This relates to the findings from this study where students prefer to form social connections with other international students from their home country. The university staff should find more creative ways to support international student organizations and activities, and more university-wide events that include both international and domestic students which should be organized (De Wit, 2011). Their integration is not only beneficial for their own adjustment; it also benefits domestic students, helping to open perspectives, deepen knowledge of other cultures, challenge stereotypical assumptions, and enhance cross-cultural awareness (Grayson, 2008; Ho et al., 2003; Telbis et al., 2014; Urban \& Palmer, 2014; Ward, 2001).

Another finding that emerged from this study is that there were multiple avenues for international graduate student to interaction, but most are either divided by their ethnicity, their country, or special interests. When an international student comes from a different county, they are sort of accustomed to the way things that are back home and tend to flock to the people from their home country. In such events, creating a coordinator role would be ideal, however, having a pamphlet with all available resources would ease the burden on international students (Slantcheva-Durst \& Knaggs, 2019). This could be linked on the website as a first point of contact for international students. Creating an international festival day would also be helpful in fostering a sense of community among the international graduate students. Research by Glass et al. (2015) found that programs and events which involved collaboration and teamwork with others from varied cultural backgrounds had a markedly strong effect on international students' sense of community.

The housing administration can foster empathy and appreciation of similarities and differences among students by sponsoring intergroup dialogues and encouraging informal cross-racial interactions (e.g., dinner events and movie nights). Additionally, these events need to be marketed better and further in advance, as many students struggle to find time in their schedules for last-minute events (Spanierman et al., 2013). These activities may provide support for international students who may encounter apathy on campus and provide opportunities for them to be better understood by their domestic counterparts. At the same time, these activities may facilitate a positive sense of community development and greater authenticity among students from all backgrounds.

The welcome program for the undergraduate residential housing could be adapted to international graduate housing so that international graduate stu- 
dents feel more welcomed on campus. Further, international student accommodation providers should make sure they have breakout spaces and communal areas that are appealing and fun to hang out in. That way, international students are more likely to socialize with other people in their position. Additionally, orientation during the move-in process would also take care of the expectations from the residents. This would lead to a norm of conduct and more friendly neighbors.

Finally, participants indicated a lack of sense of community is due to low residential satisfaction such as lack of maintenance and hygiene issues. Active tenant council can be incorporated to represent the interest of all the tenants and to have a legitimate body speaking for and backing tenant concerns and to educate and inform tenants of the nature of grievances and other issues that the tenant council will undertake.

\subsection{Limitations and Future Research Engaging with Their Own}

This research studied international students from different countries as one group; comparing experiences of students from different countries is a useful future research direction. Students from different countries and cultural backgrounds may have different experiences of acculturation and adjustment. Therefore, subgroup analysis and comparisons will provide additional insight. This study was conducted at a research intensive, land-grant university, sea-grant and space-grant institution that has a very distinctive institutional culture related to internationalization. As the international student experience is influenced by contextual and environmental factors, the research could be extended to include different institutional types. Despite these limitations, the results showed themes of challenges and support among all participants that are relevant for other universities.

\subsection{Conclusion}

Information gained from this study may provide additional areas of focus for campus administrators who are working to improve retention strategies and for those responsible for student programming on campus. Better understanding of the specific needs of this growing population may lead to reevaluation of campus resources and strategies to both recruit and retain international students. The results and recommendations presented in this study will be able to help student affairs professionals understand international graduate students' challenges and needs.

\section{Conflicts of Interest}

The authors declare no conflicts of interest regarding the publication of this paper.

\section{References}

Adriaanse, C. C. M. (2007). Measuring Residential Satisfaction: A Residential Environ- 
mental Satisfaction Scale (RESS). J Housing Built Environment, 22, 287. https://doi.org/10.1007/s10901-007-9082-9

Aiello, A., Ardone, R. G., \& Scopelliti, M. (2010). Neighbourhood Planning Improvement: Physical Attributes, Cognitive and Affective Evaluation and Activities in Two Neighbourhoods in Rome. Evaluation and Program Planning, 33, 264-275. https://doi.org/10.1016/j.evalprogplan.2009.10.004

Akinsulure-Smith, A., \& O’Hara, M. (2012). Working with Forced Migrants: Therapeutic Issues and Considerations for Mental Health Counselors. Journal of Mental Health Counseling, 34, 38-55. https://doi.org/10.17744/mehc.34.1.62rv11064465j55p

Alharbi, E. S., \& Smith, A. P. (2018). Review of the Literature on Stress and Wellbeing of International Students in English-Speaking Countries. International Education Studies, 11, 22-44. https://doi.org/10.5539/ies.v11n6p22

Altbach, P. G., \& Engberg, D. (2014). Global Student Mobility: The Changing Landscape. International Higher Education, No. 77, 11-13.

https://doi.org/10.6017/ihe.2014.77.5676

Amérigo, M., \& Aragonés, J. I. (1997). A Theoretical and Methodological Approach to the Study of Residential Satisfaction. Journal of Environmental Psychology, 17, 47-57. https://doi.org/10.1006/jevp.1996.0038

Andrade, M. S., \& Evans, N. W. (2009). Keys to Persistence: International Students in Higher Education. In M. S. Andrade, \& N. W. Evans (Eds.), International Students: Strengthening a Critical Resource (pp. 43-71). Rowman et Littlefield Education.

Arthur, N. (2017). Supporting International Students through Strengthening Their Social Resources. Studies in Higher Education, 42, 887-894. https://doi.org/10.1080/03075079.2017.1293876

Astin, A. W. (1993). Diversity and Multiculturalism on the Campus. Change: The Magazine of Higher Learning, 25, 44-49. https://doi.org/10.1080/00091383.1993.9940617

Beine, M., Noël, R., \& Ragot, L. (2014). Determinants of the International Mobility of Students. Economics of Education Review, 41, 40-54. https://doi.org/10.1016/j.econedurev.2014.03.003

BeLue, R., Taylor-Richardson, K. D., Lin, J., McClellan, L., \& Hargreaves, M. K. (2006). Racial Disparities in Sense of Community and Health Status. Journal of Ambulatory Care Management, 29, 112-124. https://doi.org/10.1097/00004479-200604000-00004

Bevis, T. B. (2002). At a Glance International Students in the United States. International Educator, 11, 12-17.

Biliczky, C. (2005). Colleges Offer Plush New Dorms. Akron Beacon Journal (OH), 5. https://web-p-ebscohost-com.ezproxy.lib.utexas.edu/ehost/detail/detail?vid=2\&sid=ce3 cb325-8f2f-494a-ab2f-42d5ee294072\%40redis\&bdata=InNpdGU9ZWhvc3QtbGl2ZQ\% $\underline{3 \mathrm{~d} \% 3 \mathrm{~d} \# \mathrm{AN}=2 \mathrm{~W} 62983316153 \& \mathrm{db}=\mathrm{n} 5 \mathrm{~h}}$

Bogdan, R., \& Biklen, S. K. (2003). Qualitative Research for Education: An Introduction to Theory and Methods. Allyn and Bacon.

Brodsky, A. E. (1996). Resilient Single Mothers in Risky Neighborhoods: Negative Psychological Sense of Community. Journal of Community Psychology, 24, 347-363. https://doi.org/10.1002/(SICI)1520-6629(199610)24:4<347::AID-JCOP5>3.0.CO;2-R

Burrell, K. (2016). Lost in the 'Churn'? Locating Neighbourliness in a Transient Neighbourhood. Environment and Planning A: Economy and Space, 48, 1599-1616. https://doi.org/10.1177/0308518X16643727

Chavis, D. M., \& Newbrough, J. R. (1986). The Meaning of "Community” in Community Psychology. Journal of Community Psychology, 14, 335-340. 
https://doi.org/10.1002/1520-6629(198610)14:4<335::AID-JCOP2290140402>3.0.CO;2$\underline{\mathrm{T}}$

Chen, J., \& Zhou, G. (2019). Chinese International Students' Sense of Belonging in North American Postsecondary Institutions: A Critical Literature Review. Brock Education Journal, 28, 48-63. https://doi.org/10.26522/brocked.v28i2.642

Cheng, D. X. (2004). Students' Sense of Campus Community: What It Means, and What to Do about It. NASPA Journal, 41, 216-234. https://doi.org/10.2202/1949-6605.1331

Da Luz Reis, A. T., \& Dias Lay, M. C. (2009). Internal and External Aesthetics of Housing Estates. Environment and Behavior, 42, 271-294.

https://doi.org/10.1177/0013916509334134

De Wit, H. (2011). Trends, Issues and Challenges in Internationalization of Higher Education. Centre for Applied Research on Economics and Management.

Denzin, N. K., \& Lincoln, Y. S. (1994). Handbook of Qualitative Research. Sage.

Duffy, K., \& Wong, F. (1996). Community Psychology. Allyn and Bacon.

Evans, S. (2009). "That Lot up There and US down Here": Social Interaction and a Sense of Community in a Mixed Tenure UK Retirement Village. Ageing and Society, 29, 199-216. https://doi.org/10.1017/S0144686X08007678

Farrell, S. J., Aubry, T., \& Coulombe, D. (2004). Neighborhoods and Neighbors: Do They Contribute to Personal Well-Being? Journal of Community Psychology, 32, 9-25. https://doi.org/10.1002/jcop.10082

Fried, M. (1984). The Structure and Significance of Community Satisfaction. Population and Environment, 7, 61-86. https://doi.org/10.1007/BF01254778

Glass, C. R., Kociolek, E., Wongtrirat, R., Lynch, R. J., \& Cong, S. (2015). Uneven Experiences: The Impact of Student-Faculty Interactions on International Students' Sense of Belonging. Journal of International Students, 5, 353-367. https://doi.org/10.32674/jis.v5i4.400

Grayson, J. P. (2008). Sense of Coherence and Academic Achievement of Domestic and International Students: A Comparative Analysis. Higher Education, 56, 473-492. https://doi.org/10.1007/s10734-007-9106-0

Grzeskowiak, S., Sirgy, M. J., Lee, D., \& Claiborne, C. B. (2006). Housing Well-Being: Developing and Validating a Measure. Social Indicators Research, 79, 503-541. https://doi.org/10.1007/s11205-005-5667-4

Hart, A. R. (2021). Increasing a Sense of Community in Campus Residences: An Action Research Study (Order No. 28416953). ProQuest Dissertations \& Theses Global. (2540472871).

https://www.proquest.com/docview/2540472871?fromopenview=true.\&pq-origsite=gsc $\underline{\text { holar }}$

Hausmann, L. R., Schofield, J. W., \& Woods, R. L. (2007). Sense of Belonging as a Predictor of Intentions to Persist among African American and White First-Year College Students. Research in Higher Education, 48, 803-839.

https://doi.org/10.1007/s11162-007-9052-9

Hegarty, N. (2014). Where We Are Now-The Presence and Importance of International Students to Universities in the United States. Journal of International Students, 4, 223-235. https://doi.org/10.32674/jis.v4i3.462

Hénard, F., Diamond, L., \& Roseveare, D. (2012). Approaches to Internationalisation and Their Implications for Strategic Management and Institutional Practice. IMHE Institutional Management in Higher Education, 11.

Hendrickson, B., Rosen, D., \& Aune, R. K. (2011). An Analysis of Friendship Networks, 
Social Connectedness, Homesickness, and Satisfaction Levels of International Students. International Journal of Intercultural Relations, 35, 281-295. https://doi.org/10.1016/j.ijintrel.2010.08.001

Heng, T. T. (2017). Voices of Chinese International Students in USA Colleges: "I Want to Tell Them That ...”. Studies in Higher Education, 42, 833-850. https://doi.org/10.1080/03075079.2017.1293873

Ho, E., Bulman-Fleming, B., \& Mitchell, B. (2003). Course Internationalization: Engaging Students as Learning Resources. University of Waterloo, Ontario: Canadian Bureau for International Education, 2003 Annual Conference.

Hourihan, K. (1984). Context-Dependent Models of Residential Satisfaction. Environment and Behavior, 16, 369-393. https://doi.org/10.1177/0013916584163004

Hu, S., \& Kuh, G. D. (2003). Maximizing What Students Get Out of College: Testing a Learning Productivity Model. Journal of College Student Development, 44, 185-203. https://doi.org/10.1353/csd.2003.0016

Hughey, J. B., \& Bardo, J. W. (1984). The Structure of Community Satisfaction in a Southeastern American City. The Journal of Social Psychology, 123, 91-99.

https://doi.org/10.1080/00224545.1984.9924517

IIE (2020, November 16). United States Hosts over 1 Million International Students for the Fifth Consecutive Year.

https://www.iie.org/Why-IIE/Announcements/2020/11/2020-Open-Doors-Report\#: :t ext=16\%2C\%202020\%E2\%80\%94\%20The\%202020\%20Open,the $\% 202019 \% 2 \mathrm{~F} 2020 \% 20$ academic\%20year

James, R. N., Carswell, A. T., \& Sweaney, A. L. (2008). Sources of Discontent: Residential Satisfaction of Tenants from an Internet Ratings Site. Environment and Behavior, 41, 43-59. https://doi.org/10.1177/0013916507310031

Johnston, K. (2016). Living on Campus vs. Commuting during College. https://www.apu.edu/articles/living-on-campus-vs-commuting-during-college/

Joseph, M. (2021). Feels Like Home: On Campus Housing and Its Effect on Sense of Belonging. Unpublished Master's Thesis, Eastern Illinois University.

https://efaidnbmnnnibpcajpcglclefindmkaj/viewer.html?pdfurl=https\%3A\%2F\%2Fthek eep.eiu.edu $\% 2$ Fcgi $\% 2$ Fviewcontent.cgi $\% 3$ Farticle $\% 3$ D $5873 \% 26$ context $\% 3$ Dtheses\&cle $\underline{\mathrm{n}=623683}$

Kashima, E. S., \& Loh, E. (2006). International Students' Acculturation: Effects of International, Conational, and Local Ties and Need for Closure. International Journal of Intercultural Relations, 30, 471-485. https://doi.org/10.1016/j.ijintrel.2005.12.003

Kuh, G. D. (2009). What Student Affairs Professionals Need to Know about Student Engagement. Journal of College Student Development, 50, 683-706. https://doi.org/10.1353/csd.0.0099

Kwon, Y. (2009). Factors Affecting International Students' Transition to Higher Education Institutions in the United States. College Student Journal, 43, 1020-2036.

LeCompte, M. D., \& Preissle, J. (1993). Ethnography and Qualitative Design in Educational Research. Academic Press.

Lee, J. J., \& Rice, C. (2007). Welcome to America? International Student Perceptions of Discrimination. Higher Education, 53, 381-409.

https://doi.org/10.1007/s10734-005-4508-3

McCarthy, M. E., Pretty, G. M. H., \& Catano, V. (1990). Psychological Sense of Community and Student Burnout. Journal of College Student Development, 31, 211-216.

McDonald, W. (Eds.) (2002). Creating Campus Community: In Search of Ernest Boyer's 
Legacy. Jossey Bass.

McKee, B. (2005). The New College Mixer. The New York Times, 1, 1.

McLachlan, D. A., \& Justice, J. (2009). A Grounded Theory of International Student Well-Being. Journal of Theory Construction \& Testing, 13, 27.

McMillan, D. W., \& Chavis, D. M. (1986). Sense of Community: A Definition and Theory. Journal of Community Psychology, 14, 6-23. https://doi.org/10.1002/1520-6629(198601)14:1<6::AID-JCOP2290140103>3.0.CO;2-I

Metro-Roland, M. (2018). Community, Identity, and International Student Engagement. Journal of International Students, 8, 1408-1421. https://doi.org/10.32674/jis.v8i3.63

Miller, F. D., Tsemberis, S., Malia, G. P., \& Grega, D. (1980). Neighborhood Satisfaction among Urban Dwellers. Journal of Social Issues, 36, 101-117. https://doi.org/10.1111/j.1540-4560.1980.tb02038.x

Moos, R. H. (1986). The Human Context: Environmental Determinants of Behavior. Krieger.

Mori, S. (2000). Addressing the Mental Health Concerns of International Students. Journal of Counseling and Development, 78, 137-144. https://doi.org/10.1002/j.1556-6676.2000.tb02571.x

Museus, S. D., Yi, V., \& Saelua, N. (2018). How Culturally Engaging Campus Environments Influence Sense of Belonging in College: An Examination of Differences between White Students and Students of Color. Journal of Diversity in Higher Education, 11, 467-483. https://doi.org/10.1037/dhe0000069

NAFSA (2019). Despite Stagnant Enrollment, International Students Contribute Nearly $\$ 41$ Billion to the U.S. Economy. https://www.nafsa.org/about/about-nafsa/new-nafsa-data-despite-stagnant-enrollment

O'Grady, L., \& Fisher, A. (2008). Psychological Sense of Community as a Framework to Explore Adolescence and Neighborhoods. The Australian Psychologist, 20, 44-57.

Obst, P. L., \& White, K. M. (2007). Choosing to Belong: The Influence of Choice on Social Identification and Psychological Sense of Community. Journal of Community Psychology, 35, 77-90. https://doi.org/10.1002/jcop.20135

OECD (2017). Education at a Glance 2017: OECD Indicators. OECD Publishing. https://doi.org/10.1787/eag-2017-en

Olivas, M., \& Lee, C. (2006). Understanding Stressors of International Students in Higher Education: What College Counselors and Personnel Need to Know. Journal of Instructional Psychology, 33, 217-222.

Patton, M. Q. (2002). Qualitative Research and Evaluation Methods. SAGE.

Pendse, A., \& Inman, A. G. (2017). International Student-Focused Counseling Research: A Year Content Analysis. Counselling Psychology Quarterly, 30, 20-47. https://doi.org/10.1080/09515070.2015.1128395

Perez, F., Fernandez-Mayoralas, G., Rivera, F., \& Abuin, J. (2001). Ageing in Place Predictors of the Residential Satisfaction of Elderly. Social Indicators Research, 54, 173-208. https://doi.org/10.1023/A:1010852607362

Potter, J., \& Cantarero, R. (2006). How Does Increasing Population and Diversity Affect Resident Satisfaction? A Small Community Case Study. Environment and Behavior, 38, 605-625. https://doi.org/10.1177/0013916505284797

Prieto-Welch, S. L. (2016). International Student Mental Health. New Directions for Student Services, 2016, 53-63. https://doi.org/10.1002/ss.20191

Rose-Redwood, C. R., \& Rose-Redwood, R. S. (2013). Self-Segregation or Global Mixing? 
Social Interactions and the International Student Experience. Journal of College Student Development, 54, 413-429. https://doi.org/10.1353/csd.2013.0062

Sarason, S. B. (1974). The Psychological Sense of Community: Prospects for a Community Psychology. Jossey-Bass.

Schroeder, C. C., \& Mable, P. (1994). Realizing the Educational Potential of Residence Halls. Jossey-Bass.

Slantcheva-Durst, S., \& Knaggs, C. (2019). Community College International Students and Their Campus Involvement. Community College Journal of Research and Practice, 43, 81-93. https://doi.org/10.1080/10668926.2017.1416316

Smith, K. M. (2011). The Relationship between Residential Satisfaction, Sense of Community, Sense of Belonging and Sense of Place in a Western Australian Urban Planned Community. Unpublished Doctoral Dissertation, Edith Cowan University. https://ro.ecu.edu.au/theses/460

Smith, R. A., \& Khawaja, N. G. (2011). A Review of the Acculturation Experiences of International Students. International Journal of Intercultural Relations, 35, 699-713. https://doi.org/10.1016/j.ijintrel.2011.08.004

Spanierman, L. B., Soble, J. R., Mayfield, J. B., Neville, H. A., Aber, M., Khuri, L., \& De La Rosa, B. (2013). Living Learning Communities and Students' Sense of Community and Belonging. Journal of Student Affairs Research and Practice, 50, 308-325. https://doi.org/10.1515/jsarp-2013-0022

Strayhorn, T. L. (2018). College Students' Sense of Belonging: A Key to Educational Success for All Students. Routledge. https://doi.org/10.4324/9781315297293

Sullivan, C., \& Kashubeck-West, S. (2015). The Interplay of International Students' Acculturative Stress, Social Support, and Acculturation Modes. Journal of International Students, 5, 1-11. https://doi.org/10.32674/jis.v5i1.438

Sun, J., Hagedorn, L. S., \& Zhang, Y. (2016). Homesickness at College: Its Impact on Academic Performance and Retention. Journal of College Student Development, 57, 943-957. https://doi.org/10.1353/csd.2016.0092

Supiano, B. (2018, April 14). How Colleges Can Cultivate Students'Sense of Belonging. https://www.chronicle.com/article/how-colleges-can-cultivate-students-sense-of-belon ging/

Telbis, N. M., Helgeson, L., \& Kingsbury, C. (2014). International Students' Confidence and Academic Success. Journal of International Students, 4, 330-341. https://doi.org/10.32674/jis.v4i4.452

Terruhn, J., \& Ye, J. (2021). Encountering Neighbors: Coexisting with Difference in Auckland's Avondale. Urban Geography, 1-19. https://doi.org/10.1080/02723638.2021.1883922

Thurber, C. A., \& Walton, E. A. (2012). Homesickness and Adjustment in University Students. Journal of American College Health, 60, 415-419.

https://doi.org/10.1080/07448481.2012.673520

Tinto, V. (1993). Building Community. Liberal Education, 79, 16-21.

Trice, A. G. (2004). Mixing IT UP: International Graduate Students' Social Interactions with American Students. Journal of College Student Development, 45, 671-687. https://doi.org/10.1353/csd.2004.0074

Unger, D. G., \& Wandersman, A. (1985). The Importance of Neighbors: The Social, Cognitive, and Affective Components of Neighboring. American Journal of Community Psychology, 13, 139-169. https://doi.org/10.1007/BF00905726 
Urban, E., \& Palmer, L. B. (2014). International Students as a Resource for Internationalization of Higher Education. Journal of Studies in International Education, 18, 305-324. https://doi.org/10.1177/1028315313511642

Uzzell, D., Pol, E., \& Badenas, D. (2002). Place Identification, Social Cohesion, and Environmental Sustainability. Environment and Behavior, 34, 26-53. https://doi.org/10.1177/0013916502034001003

Ward, C. (2001). The Impact of International Students on Domestic Students and Host Institutions.

https://www.educationcounts.govt.nz/publications/international/the impact of intern ational students on domestic students and host institutions

Ward, C., Bochner, S., \& Furnham, A. (2008). The Psychology of Culture Shock (2nd ed.). Routledge.

Wasserman, I. M. (1982). Size of Place in Relation to Community Attachment and Satisfaction with Community Services. Social Indicators Research, 11, 421-436. https://doi.org/10.1007/BF00323190

Webber, K. L., Krylow, R. B., \& Zhang, Q. (2013). Does Involvement Really Matter? Indicators of College Student Success and Satisfaction. Journal of College Student Development, 54, 591-611. https://doi.org/10.1353/csd.2013.0090

Wilson-Doenges, G. (2000). An Exploration of Sense of Community and Fear of Crime in Gated Communities. Environment and Behavior, 32, 597-611. https://doi.org/10.1177/00139160021972694

Wood, L., Frank, L. D., \& Giles-Corti, B. (2010). Sense of Community and Its Relationship with Walking and Neighborhood Design. Social Science \& Medicine, 70, 1381-1390. https://doi.org/10.1016/j.socscimed.2010.01.021

Wu, H., Garza, E., \& Guzman, N. (2015). International Student's Challenge and Adjustment to College. Education Research International, 2015, Article ID: 202753. https://doi.org/10.1155/2015/202753

Yao, C. W. (2014). Being and Belonging: A Critical Phenomenological Study of Undergraduate Chinese International Students' Sense of Belonging in Residence Halls. Unpublished Doctoral Dissertation, University of Nebraska-Lincoln University of Nebraska. https://digitalcommons.unl.edu/cehsedadfacpub/44

Zhang, J., \& Goodson, P. (2011). Acculturation and Psychosocial Adjustment of Chinese International Students: Examining Mediation and Moderation Effects. International Journal of Intercultural Relations, 35, 614-627.

https://doi.org/10.1016/j.ijintrel.2010.11.004

Zhang, Y. (2016). International Students in Transition: Voices of Chinese Doctoral Students in a U.S. Research University. Journal of International Students, 6, 175-194. https://doi.org/10.32674/jis.v6i1.487

Zhao, C., Kuh, G. D., \& Carini, R. M. (2005). A Comparison of International Student and American Student Engagement in Effective Educational Practices. The Journal of Higher Education, 76, 209-231. https://doi.org/10.1353/jhe.2005.0018 